\title{
The Effect of Low Morale and Motivation on Employees' Productivity \& Competitiveness in Jordanian Industrial Companies
}

\author{
Osama Samih Shaban ${ }^{1}$, Ziad Al-Zubi $^{1}$, Nafez Ali ${ }^{1}$, Atalla Alqotaish ${ }^{1}$ \\ ${ }^{1}$ Faculty of Economics \& Administrative Sciences, Al-Zaytoonah University of Jordan, Amman, Jordan \\ Correspondence: Osama Shaban, Faculty of Economics \& Administrative Sciences, Al-Zaytoonah University of \\ Jordan, P.O. Box 130, 11733, Amman, Jordan.
}

\author{
Received: April 26, $2017 \quad$ Accepted: May 17, $2017 \quad$ Online Published: June 7, 2017 \\ doi:10.5539/ibr.v10n7p1 URL: https://doi.org/10.5539/ibr.v10n7p1
}

\begin{abstract}
The current study aims to examine the effect of low morale and motivation on employees' productivity and competitiveness. Low productivity and loss of competitiveness are outcomes of low morale and low motivation and may sometimes lead to further undesired symptoms such as absenteeism and sabotage. A questionnaire was designed to achieve the purpose of this purpose, and it was distributed to selected accounting and management employees working in different Jordanian business environments. The number of questionnaires analyzed were (276) questionnaires. Resolution data were analyzed using the statistical program Smart PLS (Partial Least Square). The study concluded that low morale and low motivation affect productivity and competitiveness, and it also recommends that management should work on increasing productivity by increasing employees' satisfaction through re-engineering systems and processes and providing incentives, education and training.
\end{abstract}

Keywords: low morale, low motivation, productivity, competitiveness, Jordanian industrial companies

\section{Introduction}

In general, high morale leads to high productivity; but there is not always a positive correlation between the two. Close supervision, time studies, and scientific management can be applied in order to reach a high level of productivity, but sometimes, we can reach a high productivity by low morale. However, it is doubtful whether this combination can last (Rao, 2007). Renis Likert explains different combinations of morale and productivity viz: high morale and low productivity; high morale and high productivity; low morale and high productivity; and low morale and low productivity (Likert, 1932). We can say that managers have to work for improving the morale of their employees, as high morale makes for a better working environment, and it helps the organization to attain its goals easily.

Organizations want its employees to be more productive. But will motivation be enough to get things done? And what motivates our behavior? Employees are considered the most important resources, and the winning card in the hands of management. Low productivity may be traceable to poor employee motivation. The success and effectiveness of any firm depend to a large extent, on how well employees are motivated. Theories of human resource management, as well as theories of motivation, suggest that motivated employees tend to be more creative and productive, and it is wise for any management to use these theories in order to increase productivity and competitiveness (Stephen, 2014).

Competition can be defined as a contest between individuals or groups where they strive to attain and reach particular goals (Ryckman \& et al., 2009). The concept of competitiveness has been linked to early socialization processes between parents and children. Parents often teach individualism to their children and this is often characterized by making distinctions between themselves and others (Collier et al., 2010). Motivation and competitiveness go hand in hand. Individuals who are extremely motivated are also extremely competitive as they know the way and the means to accomplish their goals. On the other hand, other individuals use competition in a negative way. These individuals use competition selfishly to achieve their goals without considering the consequences to themselves and others (Collier et al., 2010).

Society places great emphasis and pressure on competition. There is a controlling focus on being competitive and successful (Ryckman \& et al., 2009). This kind of focus can cause low intrinsic motivation as individuals may feel lost between the ways (please confirm) and the gains. This concept is known as the hidden cost of 
reward; that is, reward is having the opposite effect on the individual. So, instead of motivating them to win, it causes them lower intrinsic motivation (Abuhamdeh \& Csikszentmihaly, 2009).

The current research problem focuses on how low morale and motivation of employees, who feel they are not being recognized as valuable contributors to the system, and hence get no rewards for the good work that they do, may lead to low productivity, loss of competitiveness, and sometimes, further undesired symptoms such as absenteeism and sabotage.

In order not to lose focus of the study's importance, the current research is going to cover all aspects of low morale and motivation and their effects on productivity and competitiveness. These two important aspects are attributed to employee's negative psychology. From the researchers' point of view, these two factors are very important and are worth discussing.

The objectives of the current study aim to examine the effect of low morale and motivation on employee's productivity and competitiveness. This research will try to attain the following objectives:

1- To stand on the causes of low morale and motivation;

2- To point out the effect of low morale and motivation on employee's productivity and competitiveness.

\section{Literature Review}

Morale is an elusive quality which involves feelings, emotions, attitude and perception towards the organization and its members. Positive morale is usually characterized by discipline, confidence and willingness to perform.

Low morale can be attributed to many factors such as job insecurity, lack of fair compensation policy, uncertain business conditions, and excessive outsourcing practices. Low morale affects company income, productivity, financial competitiveness and organizational objectives (Sauermann \& Cohen, 2008). Low morale is an outcome of managerial behavior where managers address their employees from a top-down command and refuse to communicate directly on workplace issues (Sauermann \& Cohen, 2008). This kind of communication results in a gap between employees and managers, which in turn leads to employee distrust, disrespect, and reduction of morale and workforce motivation (Chungsup \& et al., 2012). Low morale also causes employees to lose interest, especially when managers don't appreciate their efforts and the tasks performed (Zeynep \& Huckman, 2008). A costly indicator of low morale is high employee turnover. This happens when employees leave their jobs because they feel unhappy and have no incentives to stay. The negative effect of employee turnover is disconcerting because of its great implication both on financial and on productivity levels. Financially means the company has to hire new employees either with payment of higher salaries or by additional recruiting expenses. At the production level, the employees who leave will take with them the knowledge, skills and ability that helped contribute to the goals, profit and performance of the organization (Lee \& Liu, 2009).

Absenteeism is another costly indicator of low morale. Unjustified absenteeism increases cost and decreases productivity (Abbot, 2003). According to an article in 'The Leading Edge', "dissatisfied employees who are discontented with their bosses can have a high price tag". (Abbot, 2003). Management should work on controlling the effects of low morale through the understanding of their employees' potentials and their core work processes, understanding their abilities, enriching employees' job and recognizing their achievements (Ngambi, 2011).

The second perspective of this study is motivation. Motivation has been the core of many studies. Some studies earlier carried out in the eighties and nineties of this century have discussed this concept extensively. Mitacheel (1982), and Steers \& Peter (1983), Baron (1991) stated that motivation is the internal process that activates, guides and maintains behavior (Steers \& Porter, 1983). At the beginning of the twentieth century, other researchers such as Buchanan \& Hueznski (2004), stated that motivation is "the cognitive decision making process through which goal directed behavior is initiated, energized, directed and maintained" (Bucharan \& Huczynski, 2004). Butler \& Rose (2011) defined motivation as the course of movement, the inspiration behind activity, and the feeling within an individual that makes him want to achieve personal need or expectation (Bulter \& Rose, 2011). Recently Osabiya (2015) defined motivations as "the driving force within individuals by which they attempt to achieve specific goal in order to fulfill some needs or expectations" (Osabiya, 2015).

Achieving sustained high levels of performance is usually the aim of every organization. Employees are considered the main tools of such aimed performance, and motivation is considered the means to achieve such performance. In other words, high attention should be given to methods of motivating individuals in order to achieve the desired goals. 
The current research study links motivation with productivity. It indicated a positive correlation between motivation and the level of productivity in many organizations. Companies that use motivation to enhance a higher level of productivity are considered world class and compete globally, and this in-turn creates sustained competitiveness (Stephen, 2014). Also, researches indicate that a person who is motivated works hard, sustains a pace of hard work, and has self-directed behavior to achieve the desired goals. On the other hand, low motivation with low productivity is often considered a problem. To fully understand motivation, studies state that, there are two types of motivation: extrinsic and intrinsic. Extrinsic motivation concerns tangible, real rewards that are received by the employees, while intrinsic motivation is built inside the person and is natural to him (Bulter \& Rose, 2011). According to the individual's psychology, there is an inherent set of needs through which an individual can be satisfied through rewards for his work performance (Ozturk, 2012).

The other element concerning this study is productivity. Productivity is defined as the effective and efficient utilization of all resources; material, labor, capital, information and time (ILO, 2017). Low productivity is indicated through many signs which include poor quality of domestic outputs, lack of competitiveness of products in international markets, shortages of skills, low production technology, poor industrial relations, and poor human resource management. Research findings indicate that there is a link between motivation and productivity in the industrial sector. When an employee's needs are met, it means that he derives satisfaction from the job and eventually, this creates a motivated employee (Nwasike, 1991). All motivation theories tend to support the idea that a motivated worker willingly uses his ability in a constructive way to accomplish the tasks assigned to him. A motivated employee's work attitude is wholesome and tends toward high performance and productivity (Stephen, 2014).

In General, high motivation and high morale lead to high productivity as it was mentioned in the introduction of this research paper. Howe ver, there is not always a positive correlation between them. Close supervision, time studies, and scientific management can be applied in order to reach a high level of productivity, Renis Likert as it was stated earlier, mentioned different combinations of morale and productivity: high morale and low productivity; high morale and high productivity; low morale and high productivity; and low morale and low productivity. Managers have to work for improving the morale of their employees, as high morale makes the work a better working environment, and it helps the organization to attain its goals easily (Likert, 1932).

The final element of the study variables is competitiveness. As earlier stated, motivation and competitiveness go hand in hand together, competition is found in all aspects of life; even among brothers and sisters. Competition has a great impact on the motivation of an indi vidual. Some individuals use competition in a positive way. They use it in order to gain personal growth and to help themselves in reaching their potential goals. Other individuals use competition in a negative way. They use competition selfishly to achieve their goals without considering the consequences on themselves and others (Collier et al., 2010). Individuals who are extremely motivated are also extremely competitive as they know the way and the means to accomplish their goals.

\section{Method}

The primary data needed for the study objectives were collected through a survey conducted among different Jordanian industrial companies. The total listed industrial companies in Jordan are 64 companies, with a total of 580 employees working at different managerial levels. The research study sample size is 295 employees which were determined using the sample size formula at $95 \%$ confidence level, and $4 \%$ confidence interval, and a total of 580 employees which constitute the study population.

A questionnaire designed for this purpose was distributed randomly to the working employees taking part in actions and activities that has to do with carrying out businesses in their companies in November 2015, as well as to different managerial levels. The number of valid questionnaires analyzed was 276 out of 295 distributed which constitute $93.5 \%$ of total questionnaires distributed. The questionnaire was designed to feature 24 questions, with 9 questions specifically on low morale, 8 questions specifically on low motivation, and finally, 7 questions specifically on productivity and competitiveness. Resolution data were analyzed using the statistical program Smart PLS.

Quantitative data were collected using self-administered questionnaires, in which the employees were asked to state the likelihood (on a 5-point scale: [5] strongly agree; [4] agree; [3] neutral; [2] disagree; [1] strongly disagree).

Other Data was collected from secondary sources. Secondary data is collected from articles published by the well-known periodicals, books, and dissertations. 


\subsection{Statistical Analysis}

The Statistical Package for Social Sciences- Smart PLS was applied in analyzing the data received; Statistical Analysis tools include the followings:

1. Descriptive Statistics, mainly frequencies and percentages, were used to analyze sample characteristics according to job, educational level, professional certificates, and experience.

2. Correlation, Inter-correlation, Regression, and Path Coefficient were used to analyze and describe study variables from a statistical point.

3. Reliability Test using Cronbach's Alpha was used to test the reliability of the scale.

\subsection{Research Design}

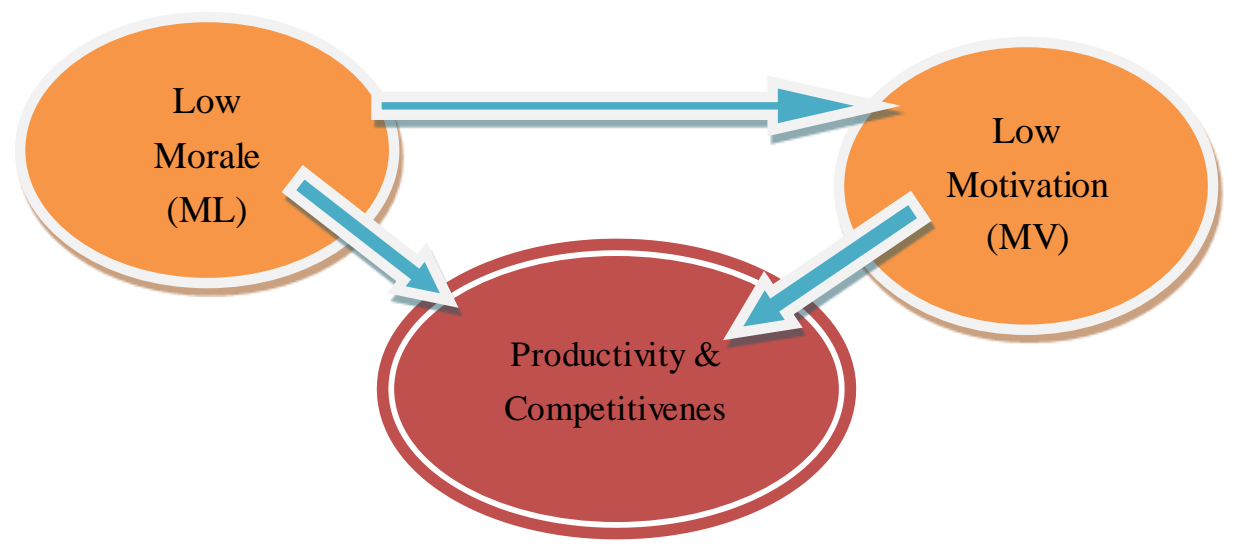

Figure 1. Research Design

The research design is formed out of three main elements that constitute the research design. The Model in Figuret-1 shows the effect of low morale and low motivation on the Productivity and Competitiveness.

\subsection{Study Hypothesis}

H1: Low morale has an effect on low motivation.

H2: Low morale has an effect on Productivity and Competitiveness.

H3: Low motivation has an effect on Productivity and Competitiveness.

\subsection{Data Analysis and Findings}

\subsubsection{Reliability Test}

Cronbach's Alpha was used to test the internal reliability of the measurement instrument. According to Uma, Sekrran a Cronbach's Alpha of 0.60 or higher is considered acceptable (Sekrran, 2003). As shown in Table 1 the Cronbach's Alphas $(\alpha)$ ranged from 0.692 to 0.916 , thus establishing the reliability of the survey questionnaire. It is obvious that all values of alpha are acceptable and relatively high. This indicates that for each measurement of a variable, the items are correlated and hence highly consistent. Table 1 shows the Cronbach's Alpha for each scale:

Table 1. Cronbach's Alpha

\begin{tabular}{ll}
\hline & Cronbach's Alpha \\
\hline Low Morale & 0.825959 \\
Low Motivation & 0.692194 \\
Productivity \& Competitiveness & 0.916212 \\
\hline
\end{tabular}

3.4.2 Sample Characteristics

$74 \%$ of the respondents were males and $26 \%$ were females; most of them were between the ages of 26 and 45 years. Most respondents had an average experience of more than 5 years. $67 \%$ of the respondents were Office Clarks, 19\% Deputy Managers, $9 \%$ Heads of departments, and, finally, $5 \%$ were executive managers. $70 \%$ of the respondents had Bachelors' degree, and the remaining 30\% had other degrees. Demographic data is shown in Table 2. 
Table 2. Demographics Data for the Research Study

\begin{tabular}{|c|c|c|c|}
\hline Variable & Group & Frequencies & $\%$ \\
\hline \multirow[t]{2}{*}{ Sex } & Male & 204 & 74 \\
\hline & Female & 72 & 26 \\
\hline Total & & 276 & $100 \%$ \\
\hline \multirow[t]{4}{*}{ Age } & Less than 25 years & 46 & 17 \\
\hline & From 26 years -35 years & 82 & 30 \\
\hline & More than 36 years -45 years & 88 & 32 \\
\hline & More than 46 years & 60 & 21 \\
\hline Total & & 276 & $100 \%$ \\
\hline \multirow[t]{2}{*}{ Professional Certificate } & Bachelors' Degree & 192 & 70 \\
\hline & Other Degree & 84 & 30 \\
\hline Total & & 276 & $100 \%$ \\
\hline \multirow[t]{4}{*}{ Job Title } & Executive & 16 & 5 \\
\hline & Head of Department & 24 & 9 \\
\hline & Deputy Manager & 52 & 19 \\
\hline & Office Clark & 184 & 67 \\
\hline Total & & 276 & $100 \%$ \\
\hline \multirow[t]{4}{*}{ Experiences } & Less than 5 years & 28 & 9 \\
\hline & From 6 years -10 years & 112 & 41 \\
\hline & More than 11 years -15 years & 90 & 33 \\
\hline & More than 16 years & 46 & 17 \\
\hline Total & & 276 & $100 \%$ \\
\hline
\end{tabular}

\subsubsection{Smart PLS Results}

The structural model results are shown in Exhibit 2. Examining the path coefficients, the numbers in Table 3 enable us to determine that Low Morale has the strongest effect on Low Motivation (0.985), followed by Low Morale on Productivity and Competitiveness (0.354). The effect between Low motivation and Productivity and Competitiveness was (0.630). The results further show that the relationship between the three variables is statistically significant. Based on their path coefficient scores, it would appear that the influence of Low Morale and Low Motivation on Productivity and Competitiveness is signific ant. However, it seems very unlikely that the hypothesized path relationship between Low Motivation and Productivity and Competitiveness which is (0.354) is relatively weak compared to path relationship between Low Morale and Low Motivation (0.985), and Low Morale on Productivity and Competitiveness (0.630) but still significant. This is as the findings of Smart PLS rule explains that the path Coefficient is significant if it is above 0.015 .

Table 3. Path coefficient

\begin{tabular}{|c|c|c|c|}
\hline Path coefficient & Low Morale & Low Motivation & Productivity \& Sustainability \\
\hline Low Morale & & 0.985097 & 0.354857 \\
\hline Low Motivation & & & 0.630448 \\
\hline Productivity \& Competitiveness & & & \\
\hline
\end{tabular}

The table above (please confirm this) shows the outcomes of R Square which represents the proportion of variation in the responses that is explained by the original model using predictor values from the test data. Moreover, the three constructs explain between $57 \%$ to $66 \%$ percent of the variance of the endogenous latent construct Low motivation $\left(\mathrm{R}^{2}=0.570\right)$, and endogenous latent construct Productivity and Competitiveness $\left(R^{2}=0.664\right)$. According to $R$ square results, it is considered moderate. Table 4 illustrates the $R$-square results

Table 4. $\mathrm{R}$ square

\begin{tabular}{|c|c|}
\hline & R Square \\
\hline \multicolumn{2}{|l|}{ Low Morale } \\
\hline Low Motivation & 0.570416 \\
\hline Productivity \& Compe titiveness & 0.664157 \\
\hline \multicolumn{2}{|c|}{$\begin{array}{l}\text { The convergent validity assessment is associated with the Average Variance Estimated (AVE) value. The } \\
\text { evaluation of validity criterion in table } 5 \text { illustrates that the AVE values of Low Morale }(0.531) \text {, Low Motivation } \\
(0.508) \text {, and Productivity and Competitiveness }(0.701) \text { are all above the cutoff point of 0.50. Therefore, all } \\
\text { reflective constructs demonstrate high levels of convergent validity (Fornell \& Larcker, 1981). Figure } 2 \\
\text { illustrates THE Smart PLS results as a whole. }\end{array}$} \\
\hline \multicolumn{2}{|l|}{ Table 5. AVE } \\
\hline & AVE \\
\hline Low Morale & 0.531549 \\
\hline Low Motivation & 0.508221 \\
\hline Productivity and Competitiveness & 0.701575 \\
\hline
\end{tabular}




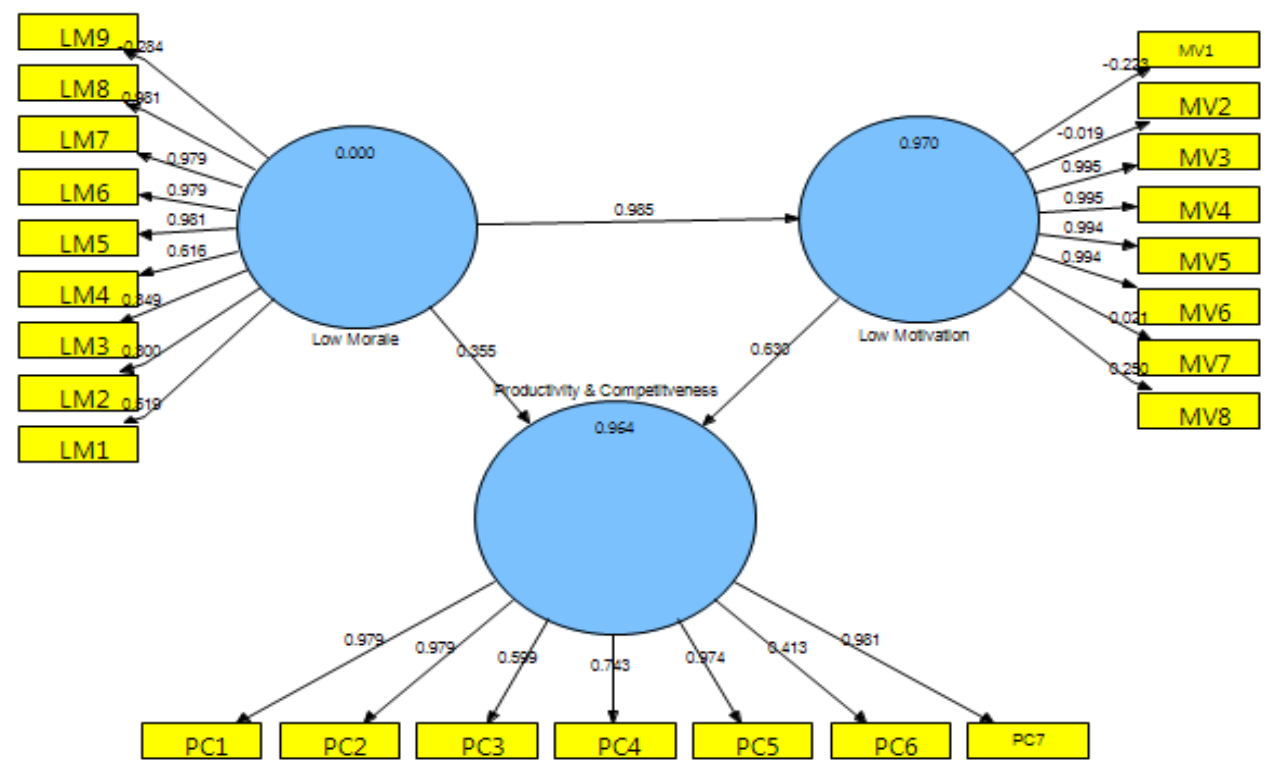

Figure 2. Model Results

\section{Conclusions \& Recommendations}

\subsection{Conclusions}

The results show that the relationship between the three variables is statistically significant. Based on their path coefficient scores, it would appear that the influence of Low Morale and Low Motivation on Productivity and Competitiveness is significant, so the research hypothesis stating that Low Morale and Low Motivation affects Productivity and Competitiveness and makes on limiting its consequences.

The Real cause behind low employee morale can include uncertain business conditions, limited upward rewards, job security issues, lack of fair compensation policy, and excessive outsourcing policy.

\subsection{Recommendations}

- Management should ensure a positive work environment which encourages confidence, discipline, and willingness to perform the job in the best possible manner.

- Management should also work on strong and sustained compensation policies that bridge the gap between the payrolls of the employees.

- Management should work on increasing productivity by increasing employees' satisfaction through re-engineering systems and processes, providing education and training.

- Encouraging practices that focus on learning of personal development competitive attitudes.

\section{References}

Abbot, J. (2003). Does Employee Satisfaction Matter? A Study to Determine Whether Low Employee Morale Affects Customer Satisfaction and Profits in the Business to Business Sector. Journal of Communication Management, 7(4), 333-339. https://doi.org/10.1108/13632540310807467

Abuhamdeh, S., \& Csikszentmihalyi, M. (2009). Intrinsic and Extrinsic Motivation Orientation in the Competitive Context: An Examination of Person-Situation Interactions. Journal of Personality, 77(5). https://doi.org/10.1111/j.1467-6494.2009.00594.x

Bucharan, D., \& Huczynski, A. (2004). Organization Behavior: An Introductory Text 5th ed., Harlow: FT/Prentice Hall.

Bulter, M., \& Rose, E. (2011). Introduction to Organizational Behavior, $1^{\text {st }}$ Ed. London IPD.

Chungsup, L., Jarrod, S., Robin, H., \& Laura, L. P. (2012). Staff Morale \& Burnout: Prevention and Possible Solutions. The Office of Recreation \& Park Resources, University of Illinois: Department of Recreation, Sport \& Tourism. 
Collier, S. A., Ryckman, R. M., Thornton, R., \& Gold, J. A. (2010). Competitive Personality Attitudes and Forgiveness of Others. The Journal of Psychology, 144, 535-543. https://doi.org/10.1080/00223980.2010.511305

Fornell, C., \& Larcker, D. F. (1981). Evaluating Structural Equation Models with Unobservable Variables and Measurement Error. Journal of Marketing Research, 18(1), 39-50. https://doi.org/10.2307/3151312

Henry, S., \& Wesley, M. C. (2008). What Makes Them Tick? Employee Motives and Firm Innovation NBER. Paper No. 14443.

Lee, H. W., \& Liu, C. H. (2009). The Relationship among Achievement Motivation, Psychological Contract and Work Attitudes. Social Behavior and Personality, 37, 321-328. https://doi.org/10.2224/sbp.2009.37.3.321

Likert, R. (1932). A technique for the measurement of attitudes. Archives of Psychology, 22(140), 1-55.

Ngambi, H. C. (2011). The Relationship Between Leadership and Employee Morale in Higher Education. African Journal of Business Management, 5(3), 762-776.

Nwasike J. (1991). Increasing Productivity in the Nigerian Public Sector. Proceeding of a National Conf. on Productivity Abuja.

Osabiya, B. J. (2015). The Effect of Employees' Motivation on Organizational Performance. Journal of Public Administration and Policy Research, 7(4), 62-75. https://doi.org/10.5897/JPAPR2014.0300

Ozturk, E. O. (2012). Contemporary Motivation Theories in Educational Psychology and Language Learning: An overview. The International Journal of Social Sciences, Vol.3, No.1 pp 33-46.

Rao, V. S. P. (2007). Human Resource Management. $2^{\text {nd }}$ Ed. D.P. House, New Delhi. P203.

Ryckman, R. M., Thornton, B., \& Gold, J. A. (2009). Assessing Competition Avoidance as a Basic Personality Dimension. The Journal of Psychology, 143(2), 175-192. https://doi.org/10.3200/JRLP.143.2.175-192

Steers, R. M., \& Porter, L. W. (1983). Motivation and Work Behavior. Ens. 3rd Ed. New York: McGraw-Hill.

Stephen, I. D. (2014). Using Motivating Theories to Enhance Productivity in Cement Manufacturing Companies in Nigeria: An Overview. The International Journal of Social Sciences, 20(1).

Uma, S., (2003). Research Method for Business: A Skill Building Approach. 7th Edition, John Wiley and Sons, New York; 2003.

Zeynep, T., \& Robert, S. H. (2008). Managing the Impact of Employee Turno ver on Performance: The Role of Process Conformance. Organization Science, 19(1), 56-68. https://doi.org/10.1287/orsc.1070.0294

\section{Copyrights}

Copyright for this article is retained by the author(s), with first publication rights granted to the journal.

This is an open-access article distributed under the terms and conditions of the Creative Commons Attribution license (http://creativecommons.org/licenses/by/4.0/). 